\title{
Bat conservation and ecotourism: the case of two abandoned tunnels in Salamanca, Western Iberia
}

\author{
Natalia Revilla-Martín ${ }^{1,2^{*}}$, Pedro Alonso-Alonso ${ }^{1,3^{*}}$, Jorge Sereno-Cadierno ${ }^{1,4}$, César Llanos-Guerrero ${ }^{1}$, \\ Luis Hernández-Tabernero ${ }^{1}$, Miguel Lizana-Avia ${ }^{1}$
}

\begin{abstract}
${ }^{1}$ Universidad de Salamanca
${ }^{2}$ Landscape Dynamics and Biodiversity programme, Forest Science and

Technology Centre of Catalonia (CTFC), Solsona, Spain

${ }^{3}$ Desert Laboratory on Tumamoc Hill, University of Arizona

${ }^{4}$ Grupo de Estudo dos Animais Salvaxes (GEAS), Rua das Barreiras, 80, 15702 Santiago de Compostela, A Coruña, Spain

*Corresponding author: nrevillam@ gmail.com, pedro.alonso.bio@gmail.com

*These authors contributed equally to this work

DOI:https://doi.org/10.14709/ BarbJ.14.1.2021.09
\end{abstract}

Keywords: artificial roost, cave-dwelling bats, Iberia, Miniopterus, Myotis, Rhinolophus, tourism, threat, tunnel, visual survey

received: January, 24th 2021 accepted: June, 6th 2021

\begin{abstract}
Underground roosts play a key role in the conservation of cave-dwelling bats. In regions where natural roosts are scarce, human-made artificial roosts can host important populations of these species. The roosts studied in the present work are two railway tunnels abandoned in 1984 that have become one of the biggest cavedwelling bats roosts in the region. Several thousands of roosting bats were reported during summer in the 1990s, and more recently, in the mid-2010s, large groups of hibernating bats and maternity colonies were found in them (Lizana-Ciudad 2015, Hernández-Tabernero et al. 2016). Now, as a measure for local economic development, a hiking route following the railroad has been habilitated and it could threaten bat colonies if many visitors enter into the tunnels. In this work, we present the data of monthly monitoring carried out during 2018 and we propose conservation measures that would allow the coexistence of the touristic hiking route and the remarkable colonies of cave-dwelling bats that the tunnels host. This monitoring shows that the occupation of the roosts is very dynamic, with different species occupying each of them in different seasons. Overall, the longest tunnel is mainly a winter hibernaculum, while the shorter one is used as a breeding roost which hosts large colonies of bats. The most abundant species in the studied roosts were Miniopterus schreibersii, Rhinolophus ferrumequinum, Myotis myotis, and Myotis blythii. These roosts seem to be part of a large transnational network of underground roosts that are well known on the Portuguese side with very limited knowledge on the Spanish side. We hope by implementing simple measures, these roosts can be preserved whilst still maintaining the hiking route for visitor enjoyment and promoting the economic development of the area.
\end{abstract}

\section{INTRODUCTION}

The biggest and most important hibernation and maternity roosts of cave-dwelling bats in the province of Salamanca, Western Iberia, are located in two abandoned railroad tunnels within the Arribes del Duero Natural Park (Fig. 1). Nowadays, the railroad has been rehabilitated as a hiking route, allowing tourists to walk through the tunnels. This activity will likely decrease the presence of bats in both seasons. It could even affect bat survival in winter as disturbances can cause the arousal of hibernating bats', therefore significantly increasing energy consumption during the wintertime (Thomas 1995, Mann et al. 2002, Luo et al. 2013).

The stretch of the railroad crossing the Natural Park is a great engineering work that includes 20 tunnels and ten bridges across only $17 \mathrm{~km}$. It used to connect the Spanish and Portuguese territories but was abandoned in 1984 for economic reasons, along with the depopulation of the region. After its abandonment, the railroad became a well-known hiking route despite the danger of crossing the high bridges which were in disrepair. In order to make the route safer and promote tourism, in 2017, the regional government started works to rehabilitate the railroad as a hiking route. The opening to the public was planned for 2018 and postponed for spring 2019. Finally the route has been opened in 2021 (Corredera 2019, 2020, 2021, Oliva 2020, Uribarri 2021).

Out of the 20 tunnels, only the two longest are known to host large bat colonies and thus were included in this study. Before this study was done, historical data was collected for the two tunnels studied. The long and straight Tunnel no. 1 seems to have been used increasinglyby bats during the last few decades. The first surveys carried out in the 1990s only recorded several hundreds of bats, both during the summer and hibernation periods (Lizana-Ciudad 2015). 
However, during the hibernation periods of 2015 and 2016, large groups of up to 5800 Miniopterus schreibersii were estimated in the tunnel. During these surveys, Rhinolophus ferrumequinum, Rhinolophus hipposideros, Rhinolophus euryale, Myotis myotis/blythii and Myotis emarginatus were also found in much lower numbers (Lizana-Ciudad 2015, Hernández-Tabernero et al. 2016).

The shorter and curved Tunnel no. 3 was already well occupied in the 1990s, at least during the warm season. M. schreibersii was the most abundant species, with 4000 and 6000 individuals respectively in 1994 and 1998. During this period, $M$. myotis/blythii increased its numbers: from 150 individuals registered in 1994 to 4000 in 1998 . Some years later, during the breeding seasons of 2015 and 2016, the estimated numbers were smaller but still substainal for the region: the counting of $M$. schreibersii resulted in 1000 and 1600 individuals in these years, while 3000 and 2300 M. myotis/blythii were also registered respectively (LizanaCiudad 2015, Hernández-Tabernero et al. 2016).

Due to the presence of the colonies, the railroad rehabilitation program included establishing fences at the entrances of both tunnels, which could be closed to prevent access during specific times of the year. They were installed in 2017. The fences are composed of a series of vertical bars and are separated from the entrance to avoid covering the tunnels completely, leaving space over them to allow for the emergence of bats (Fig. 2A). In Tunnel no. 1, the fences are intended to be permanently open, whereas those installed in Tunnel no. 3 will be closed during breeding times. In the case of Tunnel no. 3, an alternative path has been already opened and signalized, providing a way to complete the route without entering the tunnel.

The colonies have been known about for years, and valuable surveys to assess the size of the bat colonies had been carried out for several years (Lizana-Ciudad 2015, Hernández-Tabernero et al. 2016). However, these surveys were not consistent through the years, and there is no detailed information on the occupancy along the complete annual cycle. Better knowledge of the tunnels' occupation would help develop effective management strategies for the bat colonies, and to better balance their conservation needs with social or leisure activities. This will be of paramount importance since the touristic pressure will likely increase after the opening of the hiking route. With this study we aim to provide accurate data of bat occupancy throughout one complete annual cycle. This can be used as a reference for future surveys and we propose management measures which faciliate the coexistence of a hiking route alongside the large bat colonies. We hope the case study presented here will be used as a baseline for future studies of cavedwelling bats in the Arribes del Duero Natural Park.

\section{MATERIALS AND METHODS}

\section{Study area}

The tunnels are located at Arribes de Duero Natural Park in Salamanca province, Western Spain (40.95 N, 6.84 W) (Fig. 1). It is a natural region formed by deep valleys, canyons and cliffs created by the erosion of the granitic substrate by

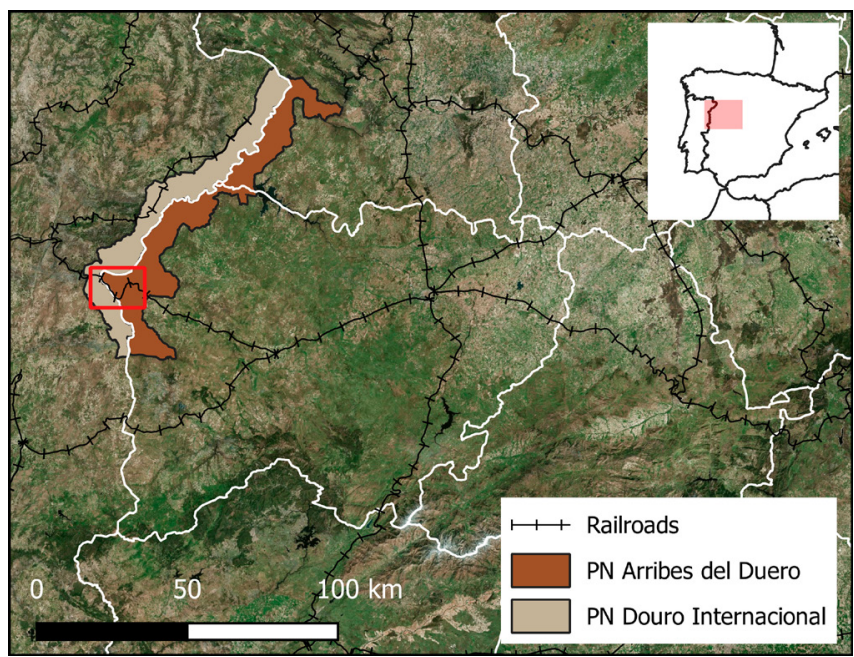

Fig. 1 - Location of the study area within the Iberian Peninsula. The red rectangle shows the approximate location of the tunnels within the abandoned railroad.

the river Duero and its tributaries. This landscape contrasts with the surrounding high plateau and determines its warmer Mediterranean climate, free of frosts and relatively wet (Sanz Herráiz et al. 2003). The region includes Spanish and Portuguese territory. On the Portuguese side, the area is protected under the name "Parque Natural do Douro Internacional". Both Natural Parks are also included in the Natura 2000 network as Special Area of Conservation (SAC), in part because of the presence of several protected bat species (Rhinolophus hipposideros, R. ferrumequinum, R. euryale, Myotis blythii, M. myotis, M. emarginatus and Miniopterus schreibersii) (Natura 2000, Palomo et al. 2007).

\section{Visual counts}

Before starting the monthly monitoring of the tunnels within the abandoned railway tunnel complex, one visit was done to each of the 20 tunnels along the railway $\left(25^{\text {th }}\right.$ January and $1^{\text {st }}$ February 2018), concluding that most of them were too short and illuminated to host colonies except from no. 1, no. 3 and no. 20. Due to bat occupancy and logistic reasons, monitoring was focused on tunnels no. 1 and 3 , and they were surveyed visually during the day once a month during 2018.

Bats were counted directly while perching scattered, and photographs were taken to count large clusters using a DSLR camera with a 70-300 mm lens and the in-built flash. Bats in the pictures were counted using the Cell Counter feature of ImageJ (Rasband 1997). This counting method is possible in the tunnels because the totality of the ceiling is visible from the ground (Fig. 2B, 2C). However, we expect a relatively large error during the breeding season when the animals were more active. This included some individuals flying inside the roost during the day. To address this bias, a conservative estimation of the flying individuals was done visually and they were added to the final count of the perched individuals photographed. We identified all bats to species level in the photographs based on Dietz \& Kiefer (2016) except Myotis blythii and M. myotis which were classified as Myotis myotis/blythii. Regarding the identification of largesized Rhinolophus spp., all were considered to belong to Rhinolophus ferrumequinum based on two considerations. 
First, all individuals within close proximity could be identified to this species by their size and fur colouration. Second, occasionally echolocation calls were recorded inside the tunnels using an EM3 detector (Wildlife Acoustics Inc) and all the constant frequency (CF) echolocation calls could be confidently assigned to $R$. ferrumequinum, based on the frequency of maximum energy (Barataud 2015). However, it is possible we failed to detect Rhinolophus euryale, visually or acoustically, as it is also present in the area. This species is considered vulnerable in the Spanish Catalogue of Endangered Species (RDL 139/2011) (Lizana-Ciudad 2015, Hernández-Tabernero et al. 2016).

\section{RESULTS}

Tunnel no. 1 hosted large hibernation colonies of $M$. schreibersii, mixed with R. ferrumequinum (Fig. 3). The biggest numbers of $M$. schreibersii were found in December, with $8843 M$. schreibersii counted, followed by January (4386 individuals) (Table 1, Fig. 4). Most M. schreibersii left the tunnel before March and returned in November. Populations of hibernating $R$. ferrumequinum were smaller, with a maximum of 282 individuals found in December (Table 1, Fig. 4). Compared to $M$. schreibersii, this species' numbers decreased later in spring and rose earlier in autumn. We also found scattered $M$. myotis/M. blythii in small numbers throughout the year, although these were mainly solitary animals (Table 1).

Tunnel no. 3 hosted breeding colonies of $M$. schreibersii and $M$. myotis/M. blythii mixed with some $R$. ferrumequinum in smaller numbers (Fig. 3). Adult M. myotis/M. blythii started to arrive in March and formed a breeding colony with stable numbers from April to June. In the same way, M. schreibersii started to arrive at the tunnel in March, but their numbers grew continuously during the spring (Fig. 4). $R$. ferrumequinum was present in the tunnel throughout the year. While no other species were recorded during the coldest months (December, January, February) (Fig. 3), more than 100 R. ferrumequinum remained in the tunnel over winter. In May and August, only around 20 R. ferrumequinum

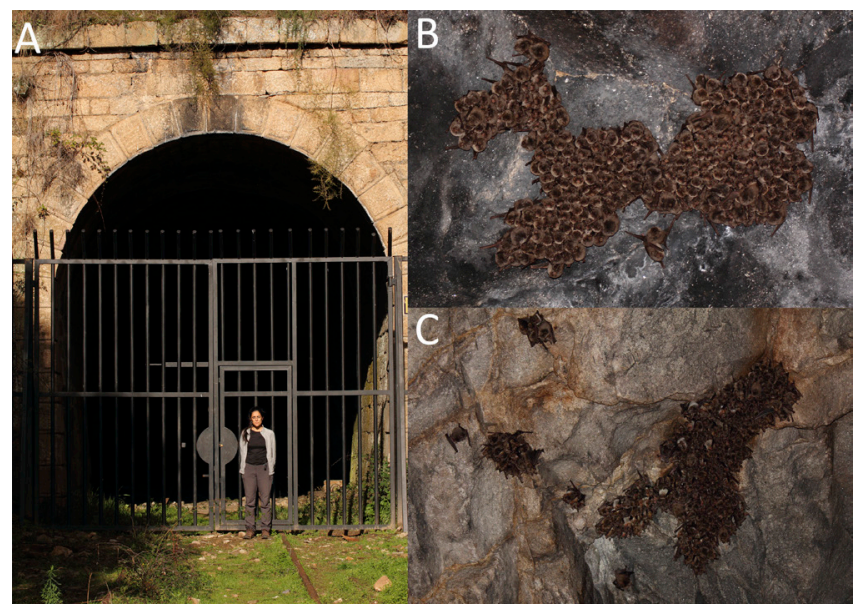

Fig. 2 - A) New fences installed in 2017 at the entrance of Tunnel no. 1 B) Group of Miniopterus schreibersii during hibernation C) mixed group of $M$. schreibersii and Myotis spp. during the breeding season.

were counted in this tunnel, while in previous and following months we counted 250-350 R. ferrumequinum (Table 1, Fig. 4).

Births took place during the last days of June and the first two weeks of July for all species. At the end of June, when it was possible to distinguish adults from furless newborn bats, we found 634 adults of $M$. schreibersii, 865 adults of M. myotis/M. blythii and 260 adults of R. ferrumequinum. Later, in July, when it was not possible to distinguish adults and juveniles, we counted a total of 1473 M. schreibersii, 1314 M. myotis/M. blythii and 351 R. ferrumequinum (Table 1, Fig.4).

In addition, only a few $R$. hipposideros used Tunnel no. 1 as hibernacula, and just two individuals were recorded in Tunnel no. 3. The least abundant occupant of the roosts was Plecotus austriacus, with two individuals registered in Tunnel no. 1 and 1 in no. 3 (Table 1). Finally, during the preliminary visits to the 20 tunnels in January, five $R$. ferrumequinum and eight $R$. hipposideros were found in Tunnel no. 20.

Table 1 - Total bat counts during the monthly visits to the roosts. M. sch: Miniopterus schreibersii, R. ferr: Rhinolophus ferrumequinum, $R$. hip: Rhinolophus hipposideros, M. spp: Myotis myotis/M. blythii and P. aus: Plecotus austriacus.

\begin{tabular}{cccccc|ccccc} 
& \multicolumn{5}{c}{ Tunnel 1 } & \multicolumn{5}{c}{ Tunnel 3 } \\
\cline { 2 - 11 } Date & M.sch & R.ferr & R.hip & M.spp & P.aus & M.sch & R.ferr & R.hip & M.spp & P.aus \\
\hline $20 / 01 / 2018$ & 4386 & 172 & 4 & 0 & 0 & 0 & 102 & 0 & 0 & 0 \\
$25 / 02 / 2018$ & 2501 & 217 & 5 & 2 & 0 & 0 & 134 & 0 & 0 & 0 \\
$25 / 03 / 2018$ & 111 & 158 & 6 & 0 & 0 & 35 & 134 & 0 & 137 & 0 \\
$21 / 04 / 2018$ & 4 & 4 & 1 & 0 & 0 & 316 & 347 & 0 & 720 & 0 \\
$19 / 05 / 2018$ & 1 & 10 & 0 & 2 & 0 & 574 & 21 & 0 & 660 & 0 \\
$01 / 06 / 2018$ & 0 & 0 & 0 & 5 & 0 & 634 & 260 & 0 & 865 & 0 \\
$22 / 07 / 2018$ & 0 & 3 & 0 & 0 & 0 & 1473 & 351 & 0 & 1314 & 1 \\
$23 / 08 / 2018$ & 30 & 15 & 0 & 15 & 0 & 1767 & 15 & 1 & 1356 & 0 \\
$29 / 09 / 2018$ & 10 & 49 & 0 & 17 & 1 & 409 & 245 & 0 & 145 & 0 \\
$21 / 10 / 2018$ & 7 & 203 & 0 & 15 & 1 & 20 & 281 & 0 & 108 & 0 \\
$27 / 11 / 2018$ & 2623 & 280 & 12 & 0 & 0 & 4 & 170 & 1 & 4 & 0 \\
$21 / 12 / 2018$ & 8843 & 282 & 2 & 82 & 0 & 0 & 130 & 0 & 0 & 0 \\
\hline
\end{tabular}


Tunnel no. 1

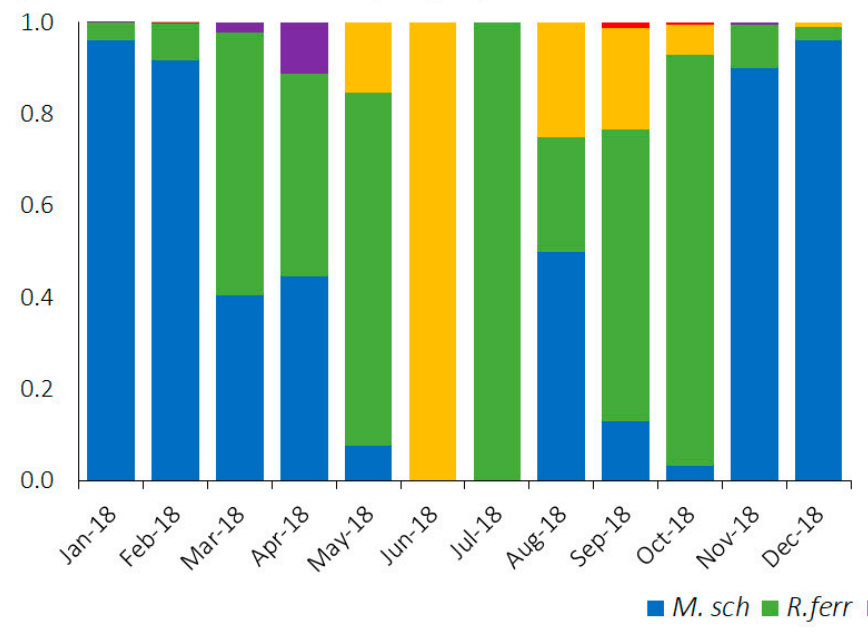

Tunnel no. 3

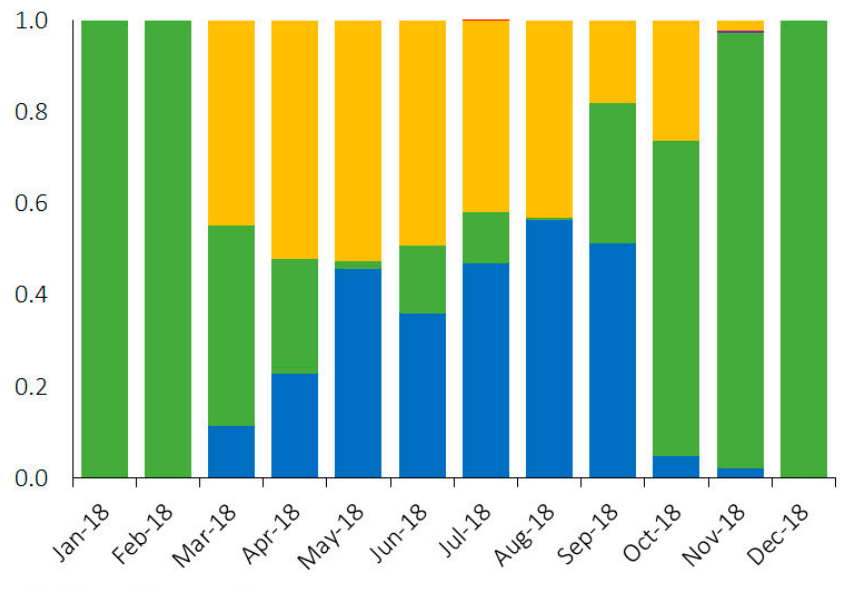

Fig. 3 - Relative abundance of the species registered in each tunnel per month during 2018. M. sch: Miniopterus schreibersii, R. ferr: Rhinolophus ferrumequinum, R. hip: Rhinolophus hipposideros, M. spp: Myotis myotis/M. blythii and P. aus: Plecotus austriacus.
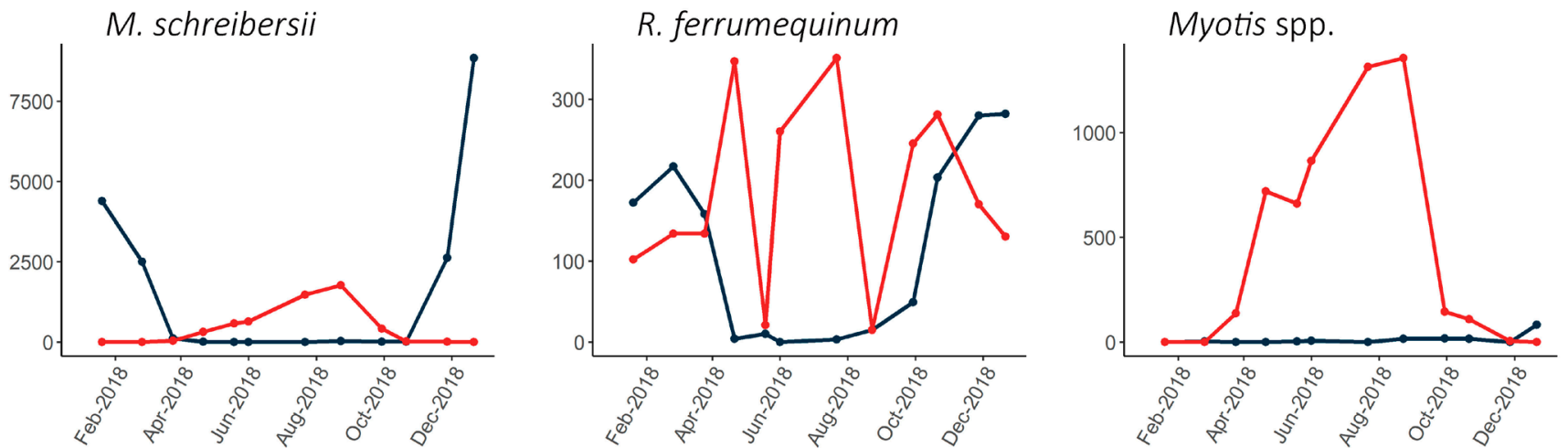

Fig. 4 - Monthly counts of the three most abundant taxa in the two surveyed roosts. The count numbers correspond to the total number of bats registered for each species or group of species. The timeline in the $\mathrm{x}$-axis is continuous and each survey is represented in the exact place that correspond to its date. Blue: Tunnel no. 1; red: Tunnel no. 3.

\section{DISCUSSION}

Large colonies of $M$. schreibersii, M. myotis/blythii and $R$. ferrumequinum, and few $R$. hipposideros were found during our surveys, showing the potential importance of artificial cavities for these cave specialist species, catalogued as vulnerable at the Spanish Catalogue of Endangered Species (Real Decreto Ley 139/2011). According to estimations included in Hernández-Tabernero et al. (2016), the population size of $M$. schreibersii in the province of Salamanca $\left(12500 \mathrm{~km}^{2}\right)$ is $60000-75000$ individuals. Our results suggest that $10 \%$ of the population could hibernate in these tunnels. According to this report by HernándezTabernero et al. (2016), M. myotis/blythii are estimated to have a population of 40000 individuals in the region of Castilla y León (a wide territory of $94222 \mathrm{~km}^{2}$ ), but in the province of Salamanca, only two other roosts have been confirmed to host large breeding colonies of these species (Lizana-Ciudad 2015). Again, according to HernándezTabernero et al. (2016), up to 10000 R. ferrumequinum could inhabit Castilla y León. However, no estimations for the local populations of $R$. ferrumequinum at the province of Salamanca are available, while important numbers of this species have only been reported at two other underground cavities in the province (Lizana-Ciudad 2015).
While Tunnel no. 1 hosts hibernation colonies, Tunnel no. 3 mainly supports maternity colonies. We hypothesize that the physical characteristics of the tunnels could be the underlying cause of the different occupation patterns. While Tunnel no.1 is straight and 1,6 km long, Tunnel no. 3 is curved and $400 \mathrm{~m}$ long. This probably creates different humidity and temperature conditions, making them more suitable for either hibernation or maternity colonies (Phelps et al. 2016).

In the context of north-western Iberia, a siliceous area where natural cavities are scarce, artificial cavities such as these tunnels gain importance as hibernation and maternity roosts. In the Portuguese territory, where $M$. schreibersii populations have been monitored during the last 20 years, most of their underground roosts have been found in abandoned mines (Ramos Pereira et al. 2009). The tunnels studied here could be part of an extensive network of $M$. schreibersii roosts across the Portuguese-Spanish border. The tunnels are located $10 \mathrm{~km}$ from the Portuguese roosts of Figueira de Castelo Rodrigo and $40 \mathrm{~km}$ from those of Mogadouro. These Portuguese roosts host maternity colonies of $M$. schreibersii, R. ferrumequinum, R. euryale and M. myotis/blythii with movement among them (Palmeirim \& Rodrigues 1992, Ramos Pereira et al. 2009). Given that $M$. 
schreibersii movements between summer and winter roosts have been found to be on average $45.1 \mathrm{~km}$ for males and 46.8 km for females (Hutterer et al. 2005, Rodrigues \& Palmeirim 2008), we hypothesize that bats hibernating at Tunnel no. 1 may migrate to the Portuguese roosts during summer. In addition, some ringed $M$. schreibersii were found in the tunnels which may have come from Portuguese research projects (Rodrigues \& Palmeirim 2008) however, it was not possible to read the codes. The constant movements of bats between roosts seem to underlie the seasonal variation of colony size and could also explain the abrupt fluctuations found in R. ferrumequinum in Tunnel no. 3 (Fig. 4). In order to properly assess population trends, monitoring should continue during the forthcoming years and collaboration across the border is desirable.

Roost site loss or disturbance have been identified as significant threats for cave-dwelling bat species across the world (Frick et al. 2020). The effect of human presence in underground roosts can disturb bat colonies and affect reproduction success (Biswas et al. 2011). Tourism, in addition to direct disturbance, has been shown to negatively affect cave-dwelling bats by driving changes in temperature and $\mathrm{CO}_{2}$ concentrations (Zhang et al. 2009) which can induce arousal from hibernation (Haarsma \& De Hullu 2012) and ultimately could lead to roost abandonment (Furey \& Racey 2016).

\section{CONSERVATION MEASURES}

Due to its importance as a breeding roost, it is essential Tunnel no. 3 is closed from at least April (when females start to arrive) until mid-September (when young bats leave the tunnel). An alternative trail has already been established to avoid crossing through the tunnel during these months. Hence closing Tunnel no. 3, when it is occupied by breeding bats, would not impact touristic use of the route and would be a highly effective conservation measure. Perimetral gating has been shown as beneficial for populations' of several cave-dwelling bats in eastern Spain, including the species breeding at this roost (Machado et al. 2017). To protect the hibernation colony of Tunnel no. 1, it should be closed at least from early November until early April. Currently, no alternative path to avoid Tunnel no. 1 has been established, but an existing trail that accesses the railway between Tunnels no. 3 and no. 4 could be signalized as an alternative route during these months. It also has to be taken into account that although the fences are over three meters high and have tips pointing outwards to avoid trespassing, during our surveys we observed people passing under them. Cementing or placing metal or wooden planks under the fences would prevent this behaviour.

We hope the simple measures proposed in this study are applied so these important bat roosts are preserved, while the hiking route can still be enjoyed by visitors that help promote the economic development of the area. Annual monitoring should be carried out in the tunnels in order to detect possible changes in the populations. Future longterm monitoring, coordinated with Portuguese colleagues, would also further our understanding of the role of these roosts within the roost network of cave-dwelling bats in Western Iberia.

\section{ACKNOWLEDGEMENTS}

We would like to acknowledge the help provided in the field by our friends and colleagues Claudia Viganò, Claudia Santamaría, Carmen Rubio, Carolina González, Jaime García, Diego Herrero, Adrián Suárez, Carmen Maestre y Juan Piñeyroa. Henar Martín, Mạ Ángeles Alonso and Pedro Alonso provided the cars used to go to the study area. We thank the anonymous reviewers for their comments and suggestions, which significantly improved and helped clarify the manuscript. Salamanca regional government (Servicio Territorial de Medio Ambiente) provided the sampling permits to study cave-dwelling bats in the Arribes del Duero Natural Park (Nt. Expt. 2017PNAD0035). No financial support was available for the present study.

\section{REFERENCES}

BARATAUD, M. (2015). Acoustic Ecology of European Bats. Species Identification and Studies of Their Habitats and Foraging Behaviour. ed.: Biotope Éditions \& Publications scientifiques du Muséum. Chicago, USA, 352 pp.

BISWAS, J., SHROTRIYA, S., RAJPUT, Y. \& SASMAL, S. (2011). Impacts of Ecotourism on Bat Habitats in Caves of Kanger Valley National Park, India. Res J of Environ Sci, 5(9): 752762. https://doi.org/10.3923/rjes.2011.752.762

CORREDERA, E. (2019). La Diputación Provincial prohíbe el acceso al Camino de Hierro hasta la apertura oficial del recorrido. www.salamancartvaldia.es.

CORREDERA, E. (2020). La Diputación abre un nuevo proceso para adjudicar el Camino de Hierro. www. salamancartvaldia.es.

CORREDERA, E. (2021). La Diputación ultima los preparativos para abrir "El Camino de Hierro" en mayo. www. salamancartvaldia.es.

DIETZ, C. \& KIEFER, A. (2016). Bats of Britain and Europe. ed.: Publishing Bloomsbury. London, United Kingdom, 398 pp.

FRICK, W. F., KINGSTON, T. \& FLANDERS, J. (2020). A review of the major threats and challenges to global bat conservation. Ann NY Acad Sci, 1469(1): 5-25. https:// doi.org/10.1111/nyas.14045

FUREY, N. M. \& RACEY, P. A. (2016). Conservation Ecology of Cave Bats. Chapter 15. In: Bats in the Anthropocene: Conservation of bats in a changing world. ed.: Springer Cham Heidelberg New York Dordrecht London. eBook, p.463-500. https://doi.org/10.1007/978-3-319-25220-9

HAARSMA, A-J. \& DE HULLU, E. (2012). Keeping bats cool in the winter: hibernating bats and their exposure to 'hot' incandescent lamplight. Wildlife Biol, 18(1): 14-23. https://doi.org/10.2981/10-067

HERNÁNDEZ-TABERNERO, L., LIZANA-CIUDAD, D. \& LIZANAAVIA, M. (2016). Estudio de las especies de Quirópteros del Parque Natural de Arribes de Duero y entorno. 
HUTTERER, R., IVANOVA, T., MEYER-CORDS, C. \& RODRIGUES, L. (2005). Bat migrations in Europe: a review of banding data and literature. ed.: German Agency for Nature Conservation. Bonn, Germany, 180 pp.

LIZANA-CIUDAD, D. (2015). Revisión bibliográfica y de campo de las colonias de murciélagos de Salamanca. Trabajo Final de Grado, Universidad de Salamanca. Salamanca, Spain.

LUO, J., JIANG, T., LU, G., WANG, L., WANG, J. \& FENG, J. (2013). Bat conservation in China: Should protection of subterranean habitats be a priority? Oryx, 47(4): 526531. https://doi.org/10.1017/S0030605311001505

MACHADO, M. C., MONSALVE, M. A., CASTELlÓ, A., ALMENAR, D., ALCOCER, A. \& SALVADOR MONRÓS, J. (2017). Population Trends of Cave-Dwelling Bats in the Eastern Iberian Peninsula and the Effect of Protecting Their Roosts. Acta Chiropterol, 19(1): 107-118. https:// doi.org/10.3161/15081109ACC2017.19.1.008

MANN, S., STEIDL, R. \& DALTON, V. (2002). Effects of Cave Tours on Breeding Myotis velifer. J Wildlife Manage, 66(3): 618-624. https://doi.org/10.2307/3803128

NATURA (2000). Standard Data Form - Es4150096. Accessed: https://natura2000.eea.europa.eu/Natura2000/SDF. aspx?site $=$ ES4150096 \& release $=10$

OLIVA, F. (2020). La Diputación espera dar "una salida definitiva" al Camino de Hierro para abrirlo "cuanto antes." www.tribunasalamanca.com.

PALMEIRIM, J. M. \& RODRIGUES, L. (1992). Plano nacional de conservação dos morcegos cavernícolas. ed.: Serviço Nacional de Parques, Reservas e Conservação da Natureza. Lisboa, Portugal, 165 pp.

PALOMO, L. J., GISBERT, J. \& BLANCO, J. C. (2007). Atlas de los Mamíferos Terrestres de España. ed.: Dirección General para la Biodiversidad-SECEM-SECEMU. Madrid, Spain, 588 pp.
PHELPS, K., JOSE, R., LABONITE, M. \& KINGSTON, T. (2016). Correlates of cave-roosting bat diversity as an effective tool to identify priority caves. Biol Conserv, 201: 201209. https://doi.org/10.1016/j.biocon.2016.06.023

RAMOS PEREIRA, M. J., SALGUEIRO, P., RODRIGUES, L., COELHO, M. M. \& PALMEIRIM, J. M. (2009). Population Structure of a Cave-Dwelling Bat, Miniopterus schreibersii: Does It Reflect History and Social Organization? J Hered, 100(5): 533-544.

RASBAND, W. S. (1997). imageJ. Bethesda, MD. ed.: National Institutes of Health. Bethesda, Maryland, USA.

REAL DECRETO LEY 139/2011. 4 de febrero, para el desarrollo del Listado de Especies Silvestres en Régimen de Protección Especial y del Catálogo Español de Especies Amenazadas. Boletín Oficial del Estado, 4 de febrero de 2011, núm. 46, pp. 20912 a 20951.

RODRIGUES, L. \& PALMEIRIM, J. M. (2008). Migratory behaviour of the Schreiber's bat: when, where and why do cave bats migrate in a Mediterranean region? J Zool, 274(2): 116-125.https://doi.org/10.1111/j.14697998.2007.00361.x

SANZ HERRÁIZ, C., MATA OLMO, R., GÓMEZ MENDOZA, J. \& ALLENDE ÁlVAREZ, F. (2003). Atlas de los paisajes de España. ed.: Ministerio de Medio Ambiente. Madrid, Spain, 683 pp.

THOMAS, D. W. (1995). Hibernating Bats are Sensitive to Nontactile Human Disturbance. J Mammal, 76(3): 940946. https://doi.org/10.2307/1382764

URIBARRI L. (2021, September 27) ¿Te gusta caminar? El Camino de Hierro en Salamanca es tu próxima ruta. www.20minutos.es.

ZHANG, L., ZHU, G., JONES, G. \& ZHANG, S. (2009). Conservation of bats in China: Problems and recommendations. Oryx, 43(2): 179-182. https://doi. org/10.1017/S0030605309432022 